Article

\title{
Disaster Governance and Vulnerability: The Case of Chile
}

\author{
Vicente Sandoval * and Martin Voss \\ Disaster Research Unit, Freie Universität Berlin, 12165 Berlin, Germany; E-Mails: vicente.sandoval@fu-berlin.de (V.S.), \\ martin.voss@fu-berlin.de (M.V.) \\ * Corresponding author
}

Submitted: 31 August 2016 | Accepted: 23 November 2016 | Published: 28 December 2016

\begin{abstract}
This exploratory work seeks to shed light on disaster governance by looking into potential linkages between the production of vulnerability and disaster governance in Chile. Our point of investigation is the case of post-disaster Chaitén and the Chilean model of Disaster Risk Management. The work begins by situating disaster governance and the production of vulnerability in a broader context of existing governance system that includes a multiplicity of actors and socio-economic, socio-ecological, and political processes. Coming from a multi-scalar perspective, we use the disaster Pressure and Release (PAR) model to enable a differentiated analysis of the multiplicity of actors, rules, and processes related to DRM that participate in the production of disaster vulnerability in the current Chaitén. With this we address the questions as to 'why' the Chilean model of DRM is prominently centralised and 'what' are the effects on the production of disaster vulnerability for the case of post-disaster Chaitén.
\end{abstract}

\section{Keywords}

Chile; disaster governance; disasters; vulnerability

Issue

This article is part of the issue "Disaster Policies and Governance: Promoting Community Resilience", edited by Naim Kapucu (University of Central Florida, USA) and Abdul-Akeem Sadiq (Indiana University-Purdue University Indianapolis, USA).

(C) 2016 by the authors; licensee Cogitatio (Lisbon, Portugal). This article is licensed under a Creative Commons Attribution 4.0 International License (CC BY).

\section{Introduction}

This exploratory work seeks to look into potential linkages between disaster governance and the production of vulnerability in order to shed light on disaster governance in Chile. Our point of investigation is the case of post-disaster Chaitén and the Disaster Risk Management (DRM) in Chile. Firstly, we offer some key definitions on disaster governance and vulnerability that underpin the exploration of potential linkages between these two processes. Secondly, we map different laws, institutions, and Territorial Planning Instruments (TPIs) to offer an overview on the model of DRM in Chile, which is characterised by its high centralisation, top-down approach, and reactive and post-event orientation. The characterisation of the DRM in Chile informs our analysis of the case of post-disaster Chaitén, a remote port-city in Southern Chile that was affected by a volcano eruption in 2008. Post-disaster Chaitén is examined from a multi-scalar per- spective where underlying causes of disaster vulnerability in the actual city can be associated with bad disaster governance, especially regarding how policy response and decision-making were applied between 2008 and 2013. Some of the post-disaster processes in Chaitén that inform our exploration are the evacuation, subsidies and benefits schemes, as well as other recovery strategies such as the Chaitén Law and the New Chaitén project. We believe that this case is compelling because it works as a proxy to discuss how governance processes during post-disaster phases are able to influence future disaster vulnerability.

In adopting a perspective of scale, we utilise the disaster Pressure and Release (PAR) model to enable a differentiated analysis of the horizontal and vertical arrangements that participate in the production of disaster vulnerability in the current Chaitén, and through which we address the questions: 'why' the Chilean model of DRM is prominently centralised and 'what' are the ef- 
fects on the production of disaster vulnerability for the case of post-disaster Chaitén. In the final section, we offer some reflections on how some unsafe conditions such as the 'erosion of trust in authorities' in Chaitén can be linked to decision-making and policies (dynamic pressures) and political centralising forces (root causes) as applied by temporally and spatially distant actors. We argue that during the progression of vulnerability, the multiplicity of actors, rules, and processes related to DRM at different geographical and social scales are extremely important and themselves reveal the grave significance of disaster governance. In order to best present the case of the DRM in Chile and Chaitén supporting this work in the next sections, the clarification of key concepts is in order.

With the term disaster governance we refer to the set of interrelated regulatory frameworks and norms, organisations, institutions, and practices within the disaster cycle (i.e. disaster response, recovery, reconstruction, mitigation, and preparedness) that are organised at multiple social and geographical scales to anticipate, cope with, resist and recover from the impact of a natural or human-made hazard (Gall, Cutter, \& Nguyen, 2014; Tierney, 2012). Disaster governance encompasses organisational and institutional actors from formal governments, private companies, and civil society bodies, to informal organisations such as networks and elites. The relationships between sets of rules, actors, and organisations can be configured in horizontal and vertical governance arrangements (Renn, 2008).

Disaster governance has an important influence on the production and prevention of the growth of vulnerability, and ultimately for the reduction of disaster risks. In simple terms, disaster risk means the possibility of negative effects in the future. That possibility solely surfaces from the interaction of human and natural environments. However, generations of socio-scientific disaster researchers have argued that 'hazards' are not the sole driver of risk and disaster losses, rather that levels of possible negative effects as well as disaster losses are in good part determined by the vulnerability and exposure of people and socio-ecological systems (e.g. Cardona et al., 2012; Voss, 2008). Thus, it is a purely societal or cultural failure to experience horrific disasters like in Haiti 2010 or in Japan in 2011 and not wholly from nature nor from anything else external to the social. Instead, one should place the blame primarily on (bad) governance.

Disaster governance and vulnerability are intrinsically connected through the entanglement of actors and dynamic processes that support and facilitate the pro- duction of disasters risks. Whilst disaster governance on the one hand refers to the complexity of multiple elements that are relevant within the never-ending disaster cycle, socio-ecological and political economy perspectives tell us that such 'web' of disaster governance can explain both the production and reduction of vulnerability, risks, and disasters on the other.

An expanded perspective on disaster vulnerability akin to that which is elaborated on in this work, is found in the Pressure and Release (PAR) model (Wisner, Blaikie, Cannon, \& Davis, 2004). In it, vulnerability production is modelled by a sequence of social, economic, and political forces at different times in a process called the 'progression of vulnerability'. According to the authors of the model, disaster vulnerability consists of the circumstances and characteristics of an element of interest (i.e. community, system, or asset) that influence said community's capacity to anticipate, cope with, resist and recover from the negative impacts of a natural or human-made extreme event, and likewise make the community susceptible to be affected in a severe manner (Wisner et al., 2004). Moreover, the PAR model offers a chain of causation to interpret disaster responsibilities. As displayed in Figure 1, the social production of disaster vulnerability is based on the idea that a more precise explanation of disasters requires us to backtrack the social relations between the impacts of a hazard on a community and a series of structural factors and processes that facilitate its production (Wisner et al., 2004).

Although the PAR model does not explicitly elaborate it, it does touch upon the multi-scalar dimension of the progression of vulnerability, sketching it as a hierarchically organised process that takes place in differentiated spaces and time. The scalar organisation of the progression of vulnerability therefore has implications for governance. For instance, when viewing the historical evolution of the state territorial organisation of Chile (i.e. from federalist to centralising models, Montecinos, 2005) we can observe how this, as a 'root cause' process, has enabled and facilitated the centralisation of decisionmaking within the domains of DRM and Disaster Risk Reduction (DRR). We can likewise observe how that ultimately has resulted in forms of 'unsafe conditions' for the people that live distant from political and economic centres, such as for the case of post-disaster Chaitén.

In terms of methodology, we adopt a disaster vulnerability framework as it allows us to look at the structural factors of risks and disasters, associated often to governance, politics, and economic issues. Although we agree

The progression of vulnerability

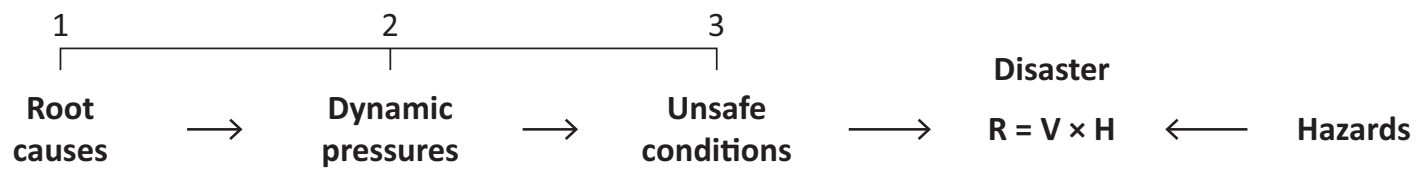

Figure 1. The disaster Pressure and Release (PAR) model. 
on the necessity of other studies on resilience and hazards, in our view, the problematique of disasters (i.e. its theoretical and practical conceptualisation, its causality debate, and its factual reduction) cannot be thoroughly understood by means of only such studies. If we are to further understand the causes of disasters, we cannot afford to neglect investigations into the principles that 'govern' their intensity and nature, which themselves are in fact more grounded in the social rather than the natural world. In this manner, this work situates itself in a political economy perspective of disasters through its application of the PAR model as the selected analytical framework in addition to other diverse qualitative research techniques. Principal among these chosen techniques was a policy and documentary analysis supported by in-depth and guided interviewing. As part of a doctoral thesis, one of the authors conducted fieldworks in Chile-including Santiago, Puerto Montt, and Chaitén-between March and September 2013, and in late-2014, to investigate the progression of vulnerability in post-disaster Chaitén. In the analysis of vulnerability drivers, the role of disaster governance emerged clearly as an influential factor. The institutional analysis draws upon the review of more than 60 documents: laws, regulatory frameworks, TPIs, institutional reports, policy papers, press release, and media archives. The documents which were selected and analysed come from (listed from the micro to macro levels): Municipality of Chaitén, Provincial Government of Palena, provincial offices of ministerial representations for Housing, Finance, Public Works, Health, Economy Development, Social Development, Agriculture, and National Property, Fire Brigade, the Government of Los Lagos Region (LLR), and the National Subsecretariat for Regional Development and Administration (SUBDERE), National Office of Emergency of the Ministry of Interior (ONEMI), Ministry of Public Works, Ministry of Housing and Urbanism (MINVU), National Institute of Statistics (INE), National Congress Library (e.g. Chaitén Law), universities, among others. These documents help us to understand the geographical distribution and hierarchical organisation of DRM and DRR in Chile as well as its repercussions on policy response and decision-making for the case of post-disaster Chaitén. In order to find convergence and corroboration, this analysis was then complemented with interviews conducted among the aforementioned institutions and with Chaitén people and community organisations. 66 interviewees were selected in total and they were approached differently using a snowball sampling technique which was also informed by institutional reports in several cases. Since the research was inductive in nature, the questions spanned and evolved from micro to macro levels. We began with 'local' questions that helped to identify some unsafe conditions (e.g. erosion of trust in authorities) for Chaitén city and its population and rounded off with questions concerning the dynamic pressures and root causes of such conditions for interviewees at regional and national levels (e.g. how was the New Chaitén project planned?).

\section{Disaster Governance in Chile}

Chile developed disaster risk management institutions, legislations, and policies relatively early, perhaps because of its history of disasters. For instance, the 1928 Talca earthquake impressed upon authorities and worker unions to implement disaster risk reduction (DRR) measures (e.g. the identification of disaster-prone areas) within the General Law of Construction and Urbanisation (Presidencia de la Republica de Chile, 1936). In 1939, the Chillán earthquake provided the basis for earthquakeresistant construction standards named the Chilean Standard for Seismic Design of Buildings № 429 (NCh429). The 1960 Valdivia earthquake and the 1965 La Ligua earthquake prompted a debate about a better coordination between actors involved in disaster response (firefighters, police, army), relief (Chilean Red Cross), preparedness and planning (Government institutions), that concluded with the creation of the ONEMI in 1974 (ONEMI, 2014).

Today, the constellation of laws, institutions, and other related regulatory frameworks informing DRM is vast and diverse in Chile. Figure 2 maps a number of analysed regulations and bodies that deal with the disaster management cycle and can influence disaster governance. In the figure, they are organised according to their nature into three differentiated categories and subcategories: system of rules (juridical and regulations), institutions, and TPIs. Moreover, these categories are arranged in a Cartesian layout to distinguish the character of the element involved, according to its orientation towards 'pre-event' or 'post-event' disaster. Likewise, they are divided into groupings whether they are more nationally or regional and locally orientated.

The ONEMI takes its place at the centre of the diagram as the primary technical agency of the state responsible for coordinating the National Civil Protection System (SNPC). The ONEMI's mission is to plan, promote, coordinate, and implement preventive actions, response, and rehabilitation against collective risk situations, emergencies, and disasters caused by natural or human action (ONEMI, 2014).

According to the guidelines of the ONEMI, each administrative level (i.e. regional, provincial, and communal) must have a Civil Protection Committee (CPC). Each CPC must internally elaborate a 'plan' to implement prevention, mitigation and preparedness actions in relation to DRM and DRR. CPCs are composed of representatives from public and private agencies and their structure varies according to the territorial level they represent. In some localities such as Chaitén that are commonly isolated and furnished with restricted financial resources and limited access to power, CPCs hardly meet and 'design' or 'implement' DRR strategies. Moreover, the ONEMI's policy establishes that the executional costs are to be covered by each of the ministries, agencies, intendant administrations, regional governments, and municipalities with its own resources (Ministerio del Interior 


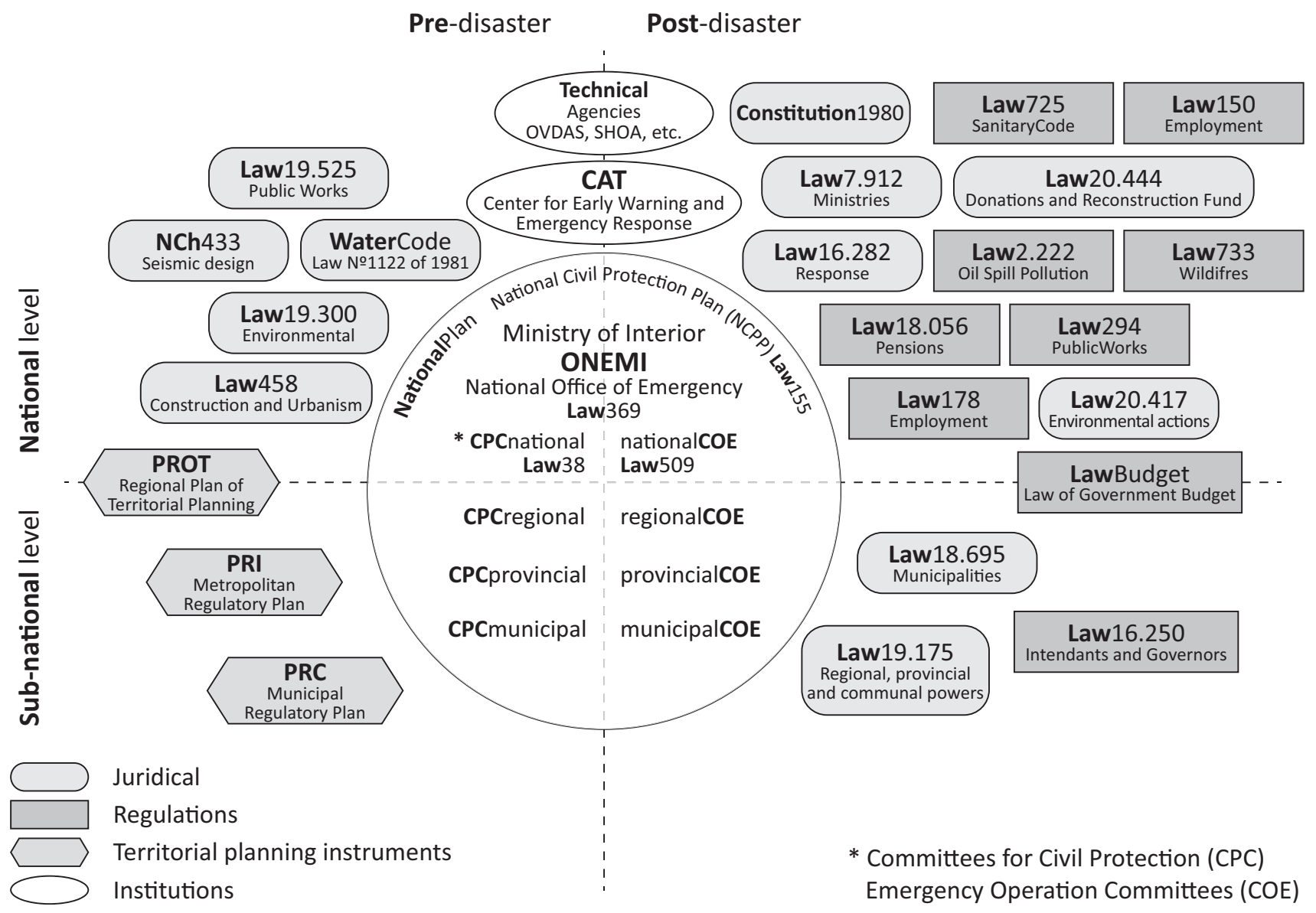

Figure 2. Map of the institutional forms related with DRM cycle in Chile.

y Seguridad Pública, 2002), thus liberating the responsibility of prioritising DRR to the respective local levels and having it compete with other specifically local demands and realities.

Despite the declaration of the ONEMI regarding 'preparedness' and 'mitigation', the office focuses mainly on 'emergency management' and response. The first indication of the latter is the level of attention paid to 'emergency issues' rather than to 'prevention' and 'preparedness'. A quick textual analysis of the Supreme Decree (DS) № 156 shows that the word 'emergency' is used twice as often in comparison to the phrases 'risk reduction', 'prevention' and 'preparedness' all together (Ministerio del Interior y Seguridad Pública, 2002).

During emergency periods, the ONEMI are configured by Emergency Operations Centres (COEs). These centres are organised at each level of the politicaladministrative order and they are responsible for decisions and actions coordinated to response and rehabilitation. COEs are headed by representatives of territorial governments that are part of the CPCs; the President of the Republic and Minister of Interior, Intendant, Governor, and Mayor respectively (see Figure 3).

The figure above reflects the hierarchical organisation of the decision-making process within the ONEMI.
Officially, the command hierarchy in the decision-making process within the ONEMI is at first 'political' in nature, then 'administrative', and lastly 'technical' (Ministerio del Interior y Seguridad Pública, 2013) ${ }^{1}$.

Apart from other individual analyses of the elements displayed in Figure 2 and 3, our intention is to map these laws, institutions, and plans to shed light on the centralisation of DRM in Chile, and highlighting its top-down approach as well as its reactive, post-event orientation (Sandoval, González-Muzzio, Wagemann, Mena, \& Ejsmentewicz, 2015). The question as to 'why' the Chilean model of DRM is prominently centralised and 'what' effects this centralisation has on the production of disaster vulnerability will be addressed in the following sections.

\subsection{Centralisation of the DRM in Chile}

A centralised model of DRM will influence the way in which disaster governance operates. Structural factors in national politics and economy affect the system of rules (Mitnick, 1980) from which the actors, institutions, and people participate in the disaster governance process. A reason why the model of DRM in Chile is highly centralised can be found in the idea that government's institutions tend to mirror or reproduce the state terri-

\footnotetext{
${ }^{1}$ The referential document was obtained via the Transparency Law and is not available to general public.
} 


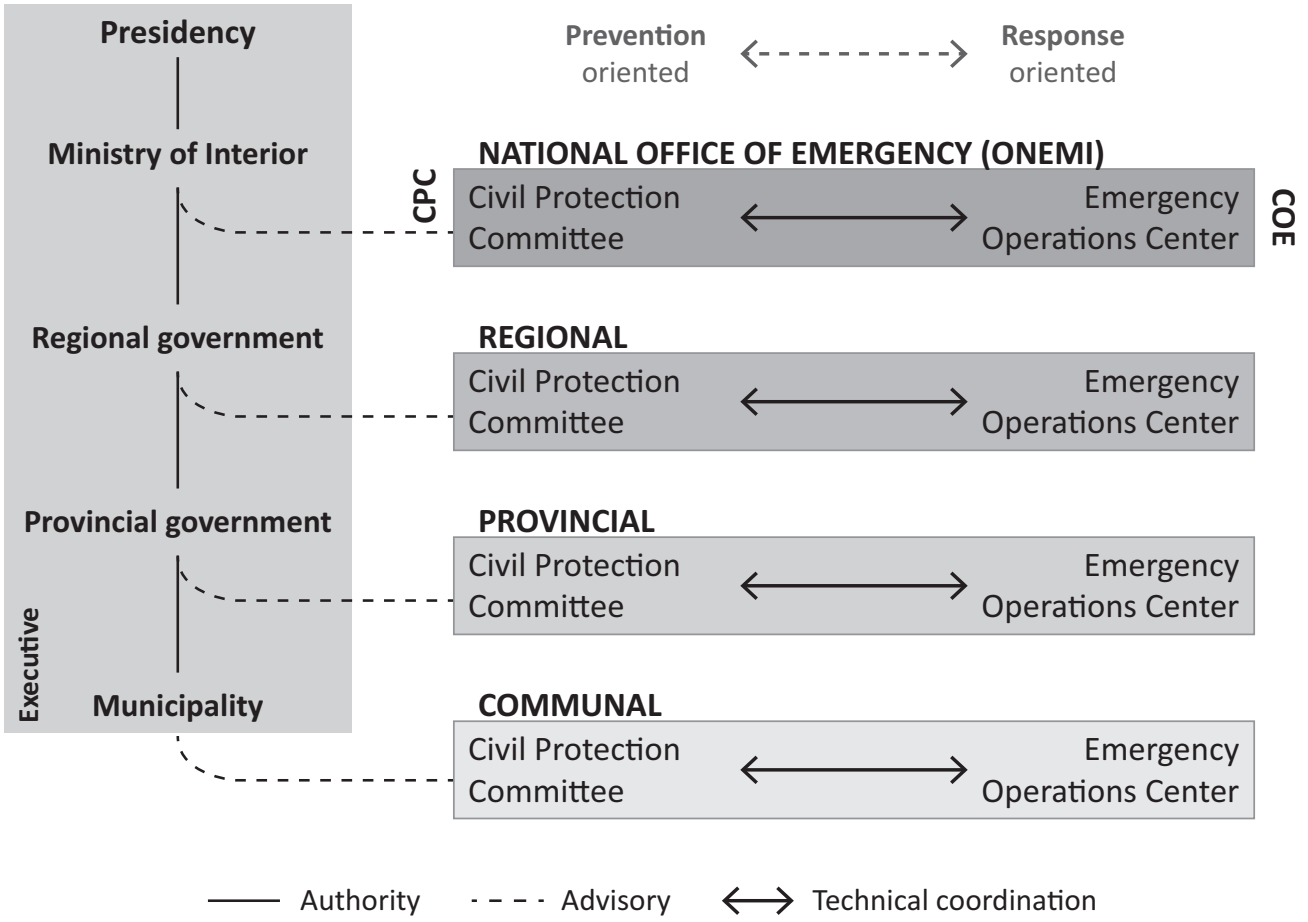

Figure 3. Structure of the National Civil Protection Plan, Chile.

torial organisation of countries (Brenner, 2000). As we have discovered, it is then not surprising that disaster related institutions assimilate the structure, hierarchical organisation, and spatial distribution of the state territorial organisation in a country politically and economically centralised like Chile: that is, the way in which the territory is spatially organised to be administrated by the government.

In a historical review of the state territorial organisation of Chile, Montecinos (2005) examined how the various geo-political scales of the national, regional, provincial, and communal have evolved since its independence from the Spanish Empire in 1810 up until in the twentyfirst century. In the timeline story of the resulting state territorial organisation, mainly referred to the political administration of the state and the economy (i.e. mode of production, structures of domination, and other social relations), one is able to distinguish a dialectical pattern involving decentralisation and regionalist tensions.

Chile's latest significant territorial reorganisation occurred in 1973, months after the coup d'état led by the General Augusto Pinochet against the democratically elected president Salvador Allende. The territorial reorganisation was based on a mode of economic poles of development characterised by the designation of 'central spatial units' determined by a city as a hub that were to connect the rest of the region. Santiago and the Metropolitan Area were established as the main centre of national development, whilst the three poles of multiregional development were Antofagasta, Valparaíso, and Concepción (Boisier, 2000). A 'third level of hierarchy' was composed by another set of 'sub-poles of regional development' which were first politically and then eco- nomically subordinated to the aforementioned regional poles (Montecinos, 2005).

On a general level, it seems that the state territorial organisation has an important influence on the geographical and scalar organisation of DRM and DRR in Chile. This is the case as other institutional forms such as in education (e.g. ministries, regional departments, schools, and so forth) are often geographically distributed and hierarchically organised in concordance with the state territorial organisation (Clark, 2014)-e.g. centralist, federalist, among others. As displayed in Figure 2 and 3, the DRM in Chile evidences the apparent centralised and top-down approaches as inherited from those approaches that dominate the actual state territorial organisation. Again, our emphasis is to examine 'centralisation' as a 'root cause' or underlying factor that facilitates the production of vulnerability in the case of postdisaster Chaitén.

From this point, we can now move on to trying to understand 'what' effects (i.e. unsafe conditions) the characteristics of such set of rules and institutions have on the production of disaster vulnerability. Upon this deduction, we will then present some reflections on disaster governance. To do so, we review the case of post-disaster Chaitén to explore disaster governance with a specific look into decision-making, community resistance, and other local-related processes that lead the production of vulnerability.

\subsection{The Case of Post-Disaster Chaitén}

Chaitén is a remote southern city in Los Lagos Region, Chile, residing about $1,000 \mathrm{~km}$ away from Santiago, the 
nation's capital. Chaitén was severely affected by a volcanic eruption in May 2008 at a time when roughly 8,000 people lived in the commune. Although no fatalities were registered, media and authorities labelled the event a 'disaster' due to its significant economic and social costs. The time span of our analysis encompasses post-disaster events from May 2008 to late 2014 (see Figure 4).

It all began with tremors felt by Chaiteninos (as people from Chaitén call themselves) the night of $30^{\text {th }}$ April 2008. During the following 24 hours, regional and local authorities, and specialists met people in Chaitén explaining to them that the shakes were probably the result of 'tectonic movements'. According to community leaders that attended those meetings:

"These meetings were very strange because from the beginning they [authorities] said that is 'only seismic' activity without risks, they explained us about the 'tectonic' movements. But in reality they had no idea... because there was an eruption the days after these meetings." (Pablo, Community leader, interviewed in July 2013) ${ }^{2}$

Effectively, a day after, on $1^{\text {st }}$ May at 23:38 these quakes culminated in a violent eruption. The first official statement asserted that the eruption could be attributed to the Michimauida volcano. However, flyovers during the next morning confirmed that the rash of activity corresponded to an unknown volcano, which was immediately named 'Chaitén', about $10 \mathrm{~km}$ north of the city. Due to the high probability of lahars and mudflows from the volcano, the ONEMI in Santiago declared 'Red Alert' to immediately initiate the evacuation of the entire city on $2^{\text {nd }}$ May. Between $2^{\text {nd }}$ and $4^{\text {th }}$ May, 8,119 people were evacuated to surrounding locations within Los Lagos Region, mainly by sea routes using private and Chilean Navy ships. According to interviewed local leaders who participated in the evacuation, there were two negative and still con- flicting issues regarding the evacuation: families were split, women and children were evacuated first, followed by men. Chaiteninos were unable to know where their family members were, neither being able to communicate to one another during the first days. Destinations of evacuated people were not pre-established, nor was there a plan to act during the evacuation. The sole objective was to preserve life and secure basic subsistence (Sandoval, Boano, González-Muzzio, \& Albornoz, 2015). The second issue was that people were told that the evacuation would last a maximum of two weeks, after which they supposedly could return to the city for their belongings and valuables. That never happened because national authorities later on decided to ban Chaitén from being inhabited for at least two years. According to Marcela, a local leader interviewed in July 2013: 'We lost all our personal belongings [referring to pictures, memories, personal valuables] because they told us that we will come back in few weeks...many left their animals and pets, they all died because we trust we could came back'. This discourse is often found in similar forms in other interviews, where the feeling of 'abandonment' and 'distance' from authorities was starting to take shape. The 'interpretation of the tremors' by authorities and specialists and the way the evacuation was conducted are conflicting issues for the Chaiteninos because these still persist in their memory and exist as a powerful reminder to not fully believe in authorities in the future. This erodes people's trust in the government: 'In case of a new evacuation I will stand firm here, I will not leave my land, my house, my assets...I do not let them take me nowhere...I prefer to die here than to live how we lived during the our time in Puerto Montt [city where she was evacuated with her family]', (Roberta, Community leader, interviewed in July 2013). Such discourse, however, does not limit itself to the experience with the first days of the emergency. The process of recovery was activated by national and regional authorities shortly after the people were evac-

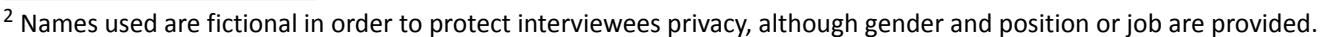

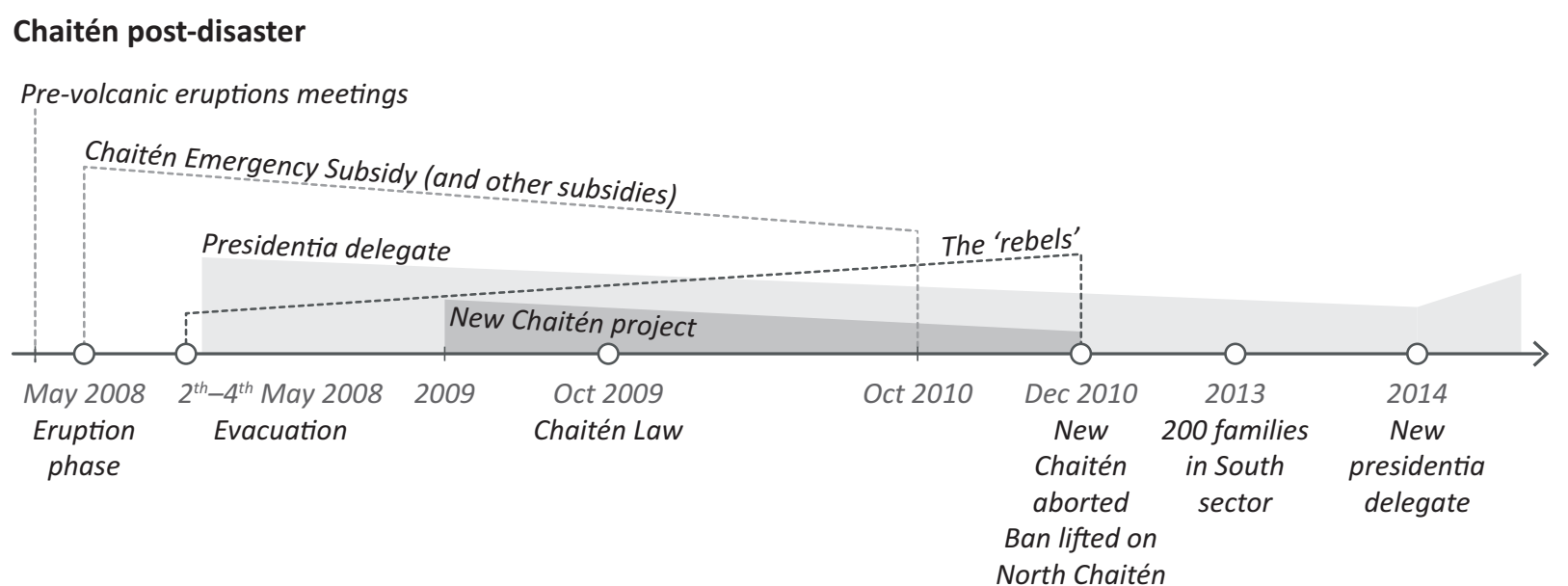

Figure 4. Chronology of events in Chaitén post-disaster from 2008 to 2014. 
uated. Several government agencies allocated special resources to support and compensate Chaitén families during the relocation processes. The main measure implemented was the 'Chaitén Emergency Subsidy'. This subsidy encompassed a monthly payment of up to US\$1,000 per family and it was delivered between May 2008 and October 2010. During the first year, more than 3,200 families benefited from it, and about 1,800 families in the second and third year. Another important compensatory measure utilised were housing subsidies. 2,235 families received a one-off housing subsidy of about US\$20,000 each (Gobierno Regional de Los Lagos, 2009). The subsidy offered special financial support to displaced people from Chaitén to resettle them in other cities such as Castro, Puerto Montt, and Puerto Varas. In some places, such as in Puerto Varas, a new 'neighbourhood' was constructed (MINVU, 2008). Likewise, other subsidies for entrepreneurship and psychological support were given (Gobierno Regional de Los Lagos, 2009; Presidencia de la República de Chile \& Narváez, 2009). As a part of the national government's strategy to encourage people to leave Chaitén definitively, the Law № 20,385 was promulgated (also called the 'Chaitén Law'). The 'Chaitén Law' allowed the state to purchase properties paying for them their market price prior the eruption. According to experts and local authorities, this strategy's objective was twofold: first, to restrict the habitability and occupancy of Chaitén because of its high risk, and second, to compensate the losses of the affected population by transferring more financial resources to them. Once the Chaitén Law was approved in October 2009, the state bought 889 properties for a total of US\$30 million-more than $80 \%$ of the total property in Chaitén (Senado de la República de Chile, 2013).

Subsidies, benefits, and other compensatory measures aimed to reduce suffering and give more opportunities to the affected people. Nevertheless, the lack of control and supervision over the benefits may have produced other undesirable effects and perhaps contributed to the production of unsafe conditions in the current Chaitén. One unforeseen effect of such subsidies may be the production of a kind of 'welfare dependency': 'People were reliant on government benefits for more than two years.... know some of them did not receive any other income...when those [benefits] ended up, they found themselves with no savings and debts...eventually, these people returned to Chaitén despite the ban' (Rosa, Local government official, interviewed in September 2013). Although 'welfare dependency' is difficult to trace in this case, a dominant narrative among specialists in Chaitén points out that debt and economic constraints (derived from mismanagement of recovery resources) were common among Chaiteninos that decided to return the city since 2010.

Next to the on-going recovery, other important processes were taking shape such as the relocation of the city itself with a project named 'New Chaitén'. Technical and planning reports supported the idea of relocating the entire city to Santa Barbara-50km north of Chaitén (Pontificia Universidad Católica de Chile [PUC], 2009). Evacuated people were consulted, a master plan was devised, and housing designs were tendered between 2009 and 2010 (MINVU, 2010). There were even some buildings constructed for the Police and Navy in Santa Barbara, but the New Chaitén project was finally aborted in December 2010 by the then recently elected President Sebastian Piñera in opposition to the previous President Bachelet's plans. This situation further frustrated Chaiteninos' trust in authorities.

Another important process was that by late 2010 , around 1,000 to 1,500 people had in fact returned to Chaitén despite the ban on inhabiting the city. The initial group was named 'the rebels' (Rojas, 2013) by the media. They were well organised (they even had a radio station with which encouraged other Chaiteninos to return to the city) and fought for their 'right' to stay in the city; 'it was a tremendous struggle against government's intentions to relocate us definitively....we stayed firm and strong because Chaitén has always been our land, we did not want to live anywhere else' (María, Community leader, interviewed in July 2013). The rebels demonstrated several times in Santiago, Puerto Montt (the regional capital), and Chaitén, gaining support from media and politicians. Thus, political shifts, community resistance, a lack of supervision on delivering benefits, the slowness and the high costs of the New Chaitén project estimated at US\$ 300 million (Silva, 2010), were some of the reasons which compounded and led to the government announcing the lift of the ban on inhabiting Chaitén in December 2010.

This decision, nevertheless, triggered some other unforeseen effects. First, it included only the North sector of Chaitén, keeping the South firmly excluded for habitation. With limited land in the North-where about 2,500 people live-and a lack of investment for expanding the housing market, today there are about 200 families informally inhabiting South Chaitén. Implications for living in the South sector are not negative per se, however, when one considers Chaitén (North and South sectors) as an entire community (as the Chaitén people do), the South sector's people found themselves comparatively helpless against future extreme events. Whilst the North sector has somehow 'resurrected' by attracting private investment and government's support in terms of schools and hospitals, also generating income opportunities for the people, and securing civil protection through mitigatory measures such as the flood barrier for the Blanco River's north bank, the South sector lacks all of these services and opportunities (Sandoval, Gonzalez-Muzzio, \& Albornoz, 2014).

\section{Final Reflections}

The post-disaster processes reviewed in the case of Chaitén indubitably occurred within a disaster governance structure. The architecture of rules, actors, and 
processes that constitute disaster risk management in Chile facilitates and limits the opportunities for disaster risk reduction, building resilience, and enables us to understand the progression of vulnerability.

One unsafe condition detected in Chaitén was the 'erosion of trust in authorities'. This facet can be linked to decision-making and policies (dynamic pressures) and political centralising forces (root causes) as applied by temporally and spatially distant actors: ONEMI in Santiago, the Presidential Delegate, parliamentary members, among others. We know that a lack of 'trust' can negatively shape vulnerability (Cutter, Boruff, \& Shirley, 2003) by altering evacuation strategies as well as by diminishing the effect of compensatory and recovery policies. Several of the testimonies collected during interviews and focal groups pointed towards one ubiquitous idea: in an eventual volcanic eruption, Chaitén's people will not follow authorities' instructions and it will likewise be difficult for them to 'believe' again in what authorities say. In other words, Chaitén's people may react negatively to the idea to 'evacuate' the city again in the future should they be called to. Upon review, it is possible to link the arguments from local leaders and Chaitén people and the 'erosion of trust in authorities' to multiple particular and specific situations which solely involved national and regional authorities: the 'misunderstanding' concerning the existence of a volcano in the area by the authorities, further specific 'negligence' concerning early and wrongly conclusions on the 'tremors' before volcano eruption; the unplanned evacuation that produced the splitting up of families and the lack of coordination between regional and local authorities; ineffective recovery process which includes poor subsidies' spending supervision; decision-making on the inhabitability of North and South sectors in Chaitén; the abandonment of the New Chaitén project after two years of planning, 'spending', and consulting efforts; and the creation of the 'parallel' authority in the Presidential Delegate which bypassed local and regional authorities.

A multi-scalar perspective on these aforementioned situations tells us that these are indeed nested in major processes or underlying causes. For instance, the evacuation of Chaitén in 2008 followed a distinct pattern of 'life preservation'. 'Life preservation' as a rule of thumb is found recurrently in the ONEMI's documents consulted on emergency management and its prevalence makes it appear as if other elements of evacuations are not important, such as the 'supervision of the aid provided' and the 'right to information'. This idea, as directed from the ONEMI national office downwards to local authorities and practitioners, may explain the reaction of authorities during the period of evacuation: both the lack of preparation in the destinations of evacuees and the subsequent splitting up of families that occurred. This also reveals a second and perhaps more crucial aspect, the centralised model of DRM in Chile. Most of the recovery strategy was planned and 'imposed' by national authorities, substantially affecting the way in which local people perceive state support during emergencies and recovery. This is not negative per se because people are not passive receivers of support, but considering Chaitén was a city exposed to a rapid onset volcanic hazard and was economically dependent on the state, it seems that the state plays a major role in promoting disaster risk reduction and resilience. The case of post-disaster Chaitén seems to point to the insufficiency in the dominant narrative which emphasises 'life preservation' as the sole indicator for successful evacuations. Rather, when evacuation, recovery and reconstruction measures are not adequately planned it can in fact help to produce other unsafe conditions (i.e. mistrust) that 'increase' vulnerability and risks. In stating this we are not trying to engage in a discussion about 'life preservation' during emergencies in particular, but rather we wish to point out that dominant narratives are not as comprehensive as DRM needs to be, and when these are embedded in a centralised model of DRM as Chile, they may negatively impact people's vulnerability in the future.

Here, it is important to note that disaster vulnerability does indeed materialise in the form of 'unsafe conditions' within specific social groups and spaces, but during its progression disaster governance-i.e. the multiplicity of actors, rules, and processes related to DRM at different geographical and social scales-its takes on an even greater significance. Macro processes such as policy response, decision-making, centralisation, and institutional bodies for DRM and DRR are not directly 'unsafe conditions' but rather the 'root causes' and 'dynamic pressures' which then facilitate the production and progression of vulnerability.

Within this paper, we took the discourse on disaster governance as a point of departure with the hope that other forms of polycentric-, adaptive-, bottom-up- and sundry-forms of governance may prevent the growth of vulnerability and risks, and stimulate the debate around this so that more optimal formats can be sought out. We argue that societies are everything but static, linear functioning, homogeneous systems but are rather highly complex, adaptive, dynamic and nonlinear developing spheres with a very heterogeneous population. This snapshot of complexity is then compounded by the history that comes with it. We believe that our conception of disaster governance can only be as good as the basic notions of these sociocultural, historic conditions are understood and the governance practices are accordingly adapted to this specific situation in space and time. There is no 'one-fits-all' approach for disaster governance. Rather, there is in fact the need to historicise and contextualise governance practices to reduce the occurrence and, if nevertheless unavoidable, the outcome of disasters.

\section{Acknowledgements}

We acknowledge support by the Open Access Publication Funds of the Freie Universität Berlin. 


\section{Conflict of Interests}

The authors declare no conflict of interests.

\section{References}

Boisier, S. (2000). Chile: La vocación regionalista del gobierno militar. EURE, 26, 81-107.

Brenner, N. (2000). The urban question as scale question: Reflections on Henri Lefebvre, urban theory and the politics of scale. International Journal of Urban and Regional Research, 24, 361-378.

Cardona, O. D., van Aalst, M. K., Birkmann, J., Fordham, M., McGregor, G., Perez, R., . . Sinh, B. T. (2012). Determinants of risk: Exposure and vulnerability. In C. B. Field, V. Barros, T. F. Stocker, D. Qin, D. J. Dokken, K. L. Ebi, M. D. Mastrandrea, K. J. Mach, G.-K. Plattner, S. K. Allen, M. Tignor, \& P. M. Midgley (Eds.), Managing the risks of extreme events and disasters to advance climate change adaptation. A special report of working groups I and II of the Intergovernmental Panel on Climate Change (IPCC) (pp. 65-108). Cambridge and New York: Cambridge University Press.

Clark, G. L. (2014). The geography of the Euro crisis: The ECB, its institutional form, functions, and performance (SSRN Working paper series). Retrieved from https://papers.ssrn.com/sol3/papers.cfm?abstract_ id $=2456154$

Cutter, S. L., Boruff, B. J., \& Shirley, W. L. (2003). Social vulnerability to environmental hazards. Social Science Quarterly, 84, 242-261.

Gall, M., Cutter, S. L., \& Nguyen, K. (2014). Governance in disaster risk management (IRDR AIRDR Publication No. 3). Beijing: Integrated Research on Disaster Risk.

Gobierno Regional de Los Lagos. (2009). Criterios en el proceso de asignación del bono de desplazamiento víctimas del Volcán Chaitén. Puerto Montt: Ministerio del Interior.

Ministerio de Vivienda y Urbanismo. (2008). Millonario plan de inversiones en zonas cercanas a Chaitén. Retrieved from http://www.minvu.cl/open site_det_20080625190648.aspx

Ministerio de Vivienda y Urbanismo. (2010). Plan maestro ciudad de Chaitén: Informe final. Santiago de Chile: MINVU.

Ministerio del Interior y Seguridad Pública. (2002). Aprueba plan nacional de proteccion civil, y deroga decreto № 155, de 1977, que aprobo el plan nacional de emergencia. Santiago de Chile: Subsecretaría del Interior. Retrieved from http://bcn.cl/1m1dw

Ministerio del Interior y Seguridad Pública. (2013). Aprueba instructivo sobre dependencia, misión, organización y funcionamiento de las direcciones regionales de protección civil y emergencia. Santiago de Chile: Ministerio del Interior.

Mitnick, B. M. (1980). The political economy of regulation: Creating, designing, and removing regulatory forms. New York, NY: Columbia University Press.
Montecinos, E. (2005). Antecedentes sobre la relación histórica centralismo y descentralización en Chile. Revista Venezolana de Gerencia, 10, 433-462.

Oficina Nacional de Emergencia de Chile. (2014). Misión y visión. Retrieved from http://www.onemi.cl/ mision-y-vision/

Pontificia Universidad Católica de Chile. (2009). Consultoría para el desarrollo de lineamientos estratégicos de reconstrucción/relocalización y Plan Maestro conceptual post-desastre Chaitén. Santiago de Chile: PUC.

Presidencia de la Republica de Chile. (1936). Ley y ordenanza general sobre construcciones y urbanización. Santiago de Chile: Parlamento de Chile.

Presidencia de la República de Chile, \& Narváez, P. (2009). Cuenta pública de la delegada presidencial paula narváez en Chaitén. Santiago de Chile: Gobierno de Chile.

Renn, O. (2008). Risk governance: Coping with uncertainty in a complex world. London: Earthscan.

Rojas, J. (2013, July 23). La reconquista de Chaitén. The Clinic. Retrieved from http://www.theclinic.cl/ 2013/07/23/la-reconquista-de-chaiten/

Sandoval, V., Boano, C., González-Muzzio, C., \& Albornoz, C. (2015). Explorando potenciales vínculos entre resilencia y justicia ambiental: El caso de Chaitén, Chile. Magallania (Punta Arenas), 43(3), 37-49.

Sandoval, V., Gonzalez-Muzzio, C., \& Albornoz, C. (2014). Resilience and environmental justice: Potential linkages. Procedia Economics and Finance, 18(1), 416-424.

Sandoval, V., González-Muzzio, C., Wagemann, E., Mena, C., \& Ejsmentewicz, D. (2015). Nueva institucionalidad para la gestión de riesgos y emergencias en Chile-Virtual roundtables. London: UCL Chilean Society. Retrieved from https://www.researchgate.net/ publication/283045692_Nueva_institucionalidad_pa ra_la_gestion_de_riesgos_y_emergencias_en_Chile

Senado de la República de Chile. (2013). Recuperación de Chaitén. Retrieved from http://www.senado.cl/ recuperacion-de-chaiten-fisco-ha-adquirido-889-in muebles-e-invirtio-cerca-de-191-millones-de-dolar es/prontus_senado/2013-08-01/162329.html

Silva, S. (2010). Piñera asegura que Chaitén será reubicado en localidad de Santa Bárbara. Diario Uchile. Retrieved from http://radio.uchile.cl/2010/05/28/ pinera-asegura-que-chaiten-sera-reubicado-en-local idad-de-santa-barbara

Tierney, K. (2012). Disaster governance: Social, political, and economic dimensions. Annual Review of Environment and Resources, 37(1), 341-363.

Voss, M. (2008). The vulnerable can't speak. An integrative vulnerability approach to disaster and climate change research. Behemoth: A Journal on Civilisation, 3(1), 39-56.

Wisner, B., Blaikie, P., Cannon, T., \& Davis, I. (2004). At risk: Natural hazards, people's vulnerability, and disasters (2nd ed.). London and New York: Routledge. 


\section{About the Authors}

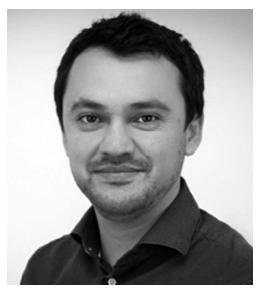

Vicente Sandoval is currently Visiting Researcher at the Disaster Research Center (DRU) in the Freie Universität Berlin, while finalizing his PhD at the Bartlett Development Planning Unit (DPU)-University College London (UCL). His research interests include disaster governance, political economy of disasters, social construction of disasters, disaster vulnerability, disaster risk management (DRM), resilience, urbanization and informal settlements, territorial planning, and globalization.

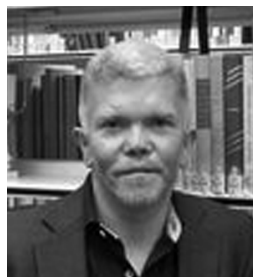

Martin Voss is Professor and Director of the Disaster Research Unit (DRU) at the Freie Universität Berlin. He holds a PhD in Sociology (summa cum laude, 2006) from the Universität Kiel, and a MA in Sociology, Psychology and Pedagogy (2001) from the same university. Professor Dr. Voss has published in peerreviewed articles, books, book chapters, and conference papers in the field of disaster research. His interests include disaster and environmental research, vulnerability and resilience, security, among others. 